\title{
Fibulin-5 mutation featuring Charcot-Marie- Tooth disease, joint hyperlaxity, and scoliosis
}

\author{
Mohamed Kazamel, MD, Michael A. Lopez, MD, PhD, Martina Bebin, MD, MPA, Kevin Bowling, PhD, \\ Bruce R. Korf, MD, PhD, Gregory S. Barsh, MD, PhD, Gregory M. Cooper, PhD, Anna C.E. Hurst, MD, and \\ Eroboghene E. Ubogu, MD
}

Neurol Genet 2020;6:e476. doi:10.1212/NXG.0000000000000476

\author{
Correspondence \\ Dr. Kazamel \\ mkazamel@uabmc.edu
}

Fibulin-5 (FBLN5) is an extracellular matrix glycoprotein expressed in elastic fiber-rich tissues. ${ }^{1}$ Mutations affecting the first epidermal growth factor domain feature a spinal Charcot-MarieTooth (CMT) phenotype, whereas the $\mathrm{C}$-terminus c.1117C $>\mathrm{T}$ variant causes demyelinating sensorimotor polyneuropathy. ${ }^{2}$ Besides CMT, FBLN5 mutations also feature age-related macular degeneration and cutis laxa. ${ }^{3}$ FBLN5-associated CMT was reported in 6 families from Austria, ${ }^{2}$ the Czech Republic, ${ }^{4}$ and China, ${ }^{5}$ with 4 possessing the c.1117C $>\mathrm{T}$ (p.Arg373Cys) mutation. ${ }^{2,4,5}$ Joint hyperlaxity and scoliosis were reported in 1 spinal CMT Austrian family due to a p.Gly90Ser mutation, but never with p.Arg373Cys-associated CMT-1. ${ }^{2}$ We describe the phenotype of a family with FBLN5-associated CMT-1 featuring younger symptom onset, joint hyperlaxity, and scoliosis.

\section{Results}

The proband (III/1) is a 14-year-old girl who reported a 2-year history of insidious onset nonprogressive feet paresthesias and distal symmetric lower limb weakness manifesting as easy tripping while playing soccer. There was no history of carpal tunnel syndrome (CTS), neuropathic pain, or muscle cramps. General examination showed mild right-deviating scoliosis. She could touch her radial forearm with her thumb (figure, A) and had significant high-arch feet (figure, B). Motor examination showed 4/5 muscle strength in arm external rotators, ankle dorsiflexors, toe extensors, and 5-/5 in ankle evertors. Sensory examination showed decreased pinprick sensation to midlegs and light touch to midfeet and knuckles. Vibration sense was reduced at the hallux with preserved proprioception. Deep tendon reflexes (DTRs) were bilaterally absent at biceps and diminished at brachioradialis and triceps.

Her 46-year-old father (II/2) reported an 18-month history of insidious onset progressive bilateral toe tingling, followed by numbness without neuropathic pain or weakness. He had chronic Raynaud phenomenon in his hands. He screened positive for scoliosis during high school. His 72-year-old mother has "curled toes." General examination showed significant highfeet arches. Neurologic examination was remarkable for 5-/5 strength in both arm external rotators, finger extensors, thumb abductors, toe extensors, and right ankle dorsiflexors. DTRs were preserved all over. He had symmetrically decreased pinprick and light touch sensation to the ankles and decreased hallux vibration sense with intact proprioception. Her twin brother (III/2) reported feet tingling sensations. He also experienced Raynaud phenomenon in his hands and had distal joint hyperlaxity (figure, C). Neurologic examination showed 5-/5 strength in his left finger extensors and 4/5 strength in finger and thumb abductors. Sensory examination showed reduced hallux vibratory sense. DTRs were diminished in the biceps, brachioradialis, and ankle bilaterally.

From the Department of Neurology (M.K., M.B., E.E.U.), University of Alabama at Birmingham (UAB); Department of Pediatrics (M.A.L., M.B.), Children's of Alabama | UAB; HudsonAlpha Institute for Biotechnology (K.B., G.S.B., G.M.C.), Huntsville, AL; and Department of Genetics (B.R.K., A.C.E.H.), UAB. 


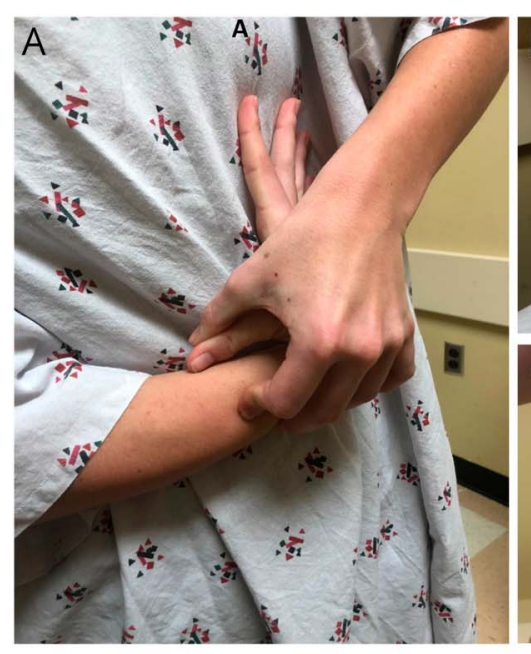

E

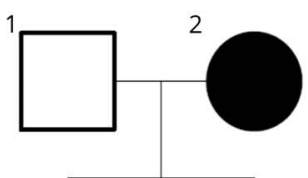

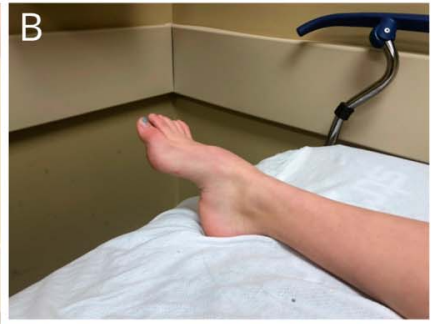

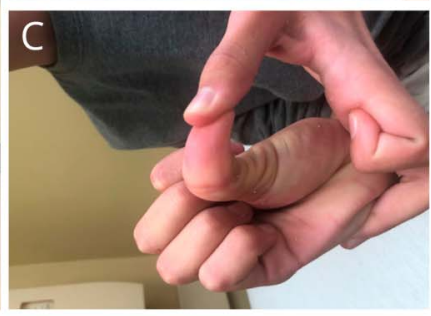

3

4

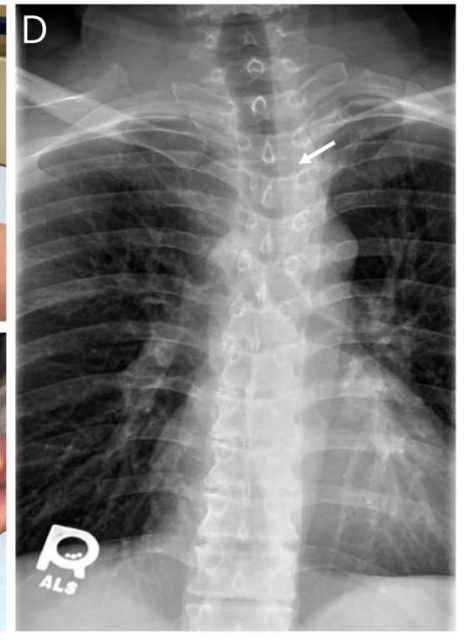

$\mathrm{F}^{\mathrm{cA}} \mathrm{II} / 1$
II

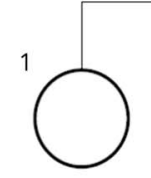

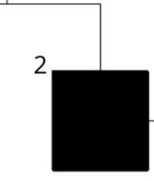
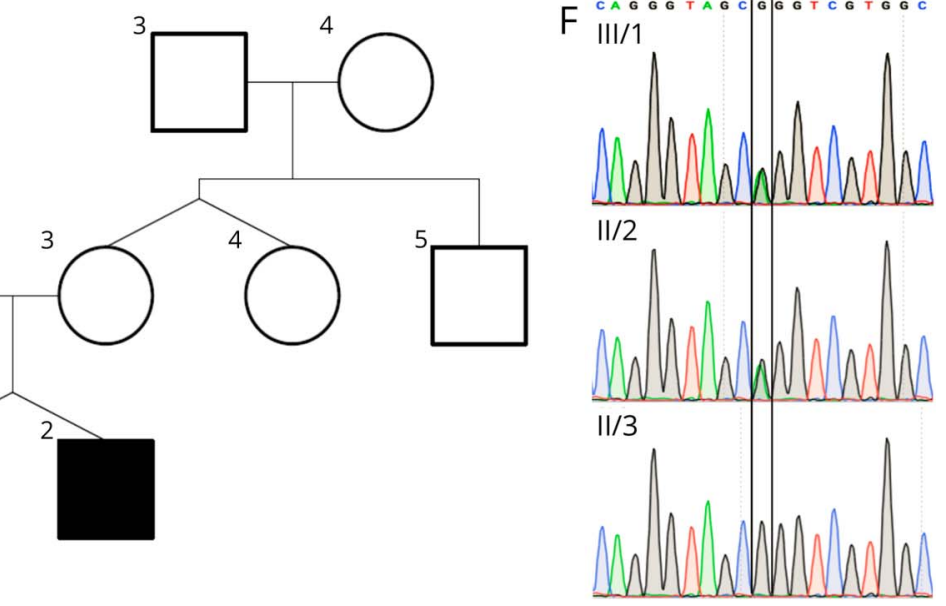

Distal joint hyperlaxity (A) and high-arch feet in the proband (B), distal interphalangeal joint hyperlaxity in the twin brother (C), and upper thoracic left-sided scoliosis (arrow) in the proband's father (D). Family pedigree shows the autosomal dominant inheritance pattern involving 3 generations of the father's family (E). Electropherogram (F) illustrates the heterozygous detection of chr14:92343899G $>A$ in the proband (III/1) and father (II/2) and the absence of the variant in the mother (II/3) who has no personal or family history of neuropathy.

Laboratory panels were unremarkable in all patients, including hepatic, renal, thyroid function tests, blood counts and differential, serum electrolytes, A1c, rheumatologic markers, B1, B12 vitamins, and serum immunofixation. Comprehensive CMT gene panel was negative in the father (supplementary material, links.lww.com/NXG/A275). The father's spine radiographs showed upper thoracic scoliosis (figure, D). Electrodiagnostic studies demonstrated a chronic demyelinating, nonlength-dependent sensorimotor polyneuropathy with no conduction blocks or temporal dispersions in all patients. This was mixed with axonal loss, more so in the twin brother than the father as evidenced by absent lower limb sensory responses and mild chronic reinnervation changes on needle EMG. Blink reflex was not performed. Trio whole-genome sequencing revealed a paternally inherited (figure, E) heterozygous pathogenic missense FBLN5 variant (c.1117C>T, p.Arg373Cys), confirmed by Sanger sequencing in the proband and her father (figure, F).

\section{Discussion}

We report the fourth known family with FBLN5-related CMT-1. The younger symptom onset in this family, compared with the European and Chinese families, could be related to the demanding proband's sporting activities causing earlier symptom awareness. The earliest previously reported onset of FBLN5-associated CMT-1 symptoms was at the age of 25 years. ${ }^{2}$ Macular degeneration is likely age dependent because this was not present in our family or the Czech family, whose oldest member was 61, but observed in an Austrian and a Chinese patient examined at the age of 81 years. ${ }^{2,4,5}$ Joint hyperlaxity and scoliosis were reported previously only in p.Gly90Ser-associated spinal CMT. ${ }^{2}$

Our family did not report symptoms suggestive of CTS such as the other families. However, the reduced finger pinprick perception, diminished upper limb reflexes, and mild hand weakness are manifestations of early upper limb involvement. 
This feature should raise suspicion of FBLN5-associated CMT-1 because it was observed in the previous cohorts and is relatively uncommon in other CMT neuropathies. This report expands the clinical spectrum of FBLN5-associated CMT-1 to include adolescent onset, scoliosis, and joint hyperlaxity. The p.Arg373Cys variant remains the only reported mutation linked to FBLN5-associated CMT-1. Longitudinal follow-up and identification of more cases are required for more comprehensive phenotype description. Testing for FBLN5 mutations is not generally performed in commercial CMT gene panels, thus we advocate its future inclusion based on this report.

\section{Acknowledgment}

The authors acknowledge the Alabama Genomic Health Initiative (AGHI), funded by the State of Alabama, for making the whole-genome sequencing diagnosis possible.

\section{Study funding}

This research did not receive any specific grant from funding agencies in the public, commercial, or not-for-profit sectors.

\section{Disclosure}

The authors report no relevant disclosure or conflict of interests. Go to Neurology.org/NG for full disclosures.

\section{Publication history}

Received by Neurology: Genetics March 3, 2020. Accepted in final form June 1, 2020.

\section{Appendix Authors}

\begin{tabular}{lll}
\hline Name & Location & Contribution \\
\hline $\begin{array}{l}\text { Mohamed } \\
\text { Kazamel, }\end{array}$ & $\begin{array}{l}\text { University of Alabama } \\
\text { at Birmingham }\end{array}$ & $\begin{array}{l}\text { Design and conceptualized the } \\
\text { study, analyzed the data, and } \\
\text { drafted the manuscript for } \\
\text { intellectual content }\end{array}$ \\
\hline
\end{tabular}

Appendix (continued)

\begin{tabular}{|c|c|c|}
\hline Name & Location & Contribution \\
\hline $\begin{array}{l}\text { Michael A. } \\
\text { Lopez, MD, } \\
\text { PhD }\end{array}$ & $\begin{array}{l}\text { Children's of Alabama, } \\
\text { Birmingham }\end{array}$ & $\begin{array}{l}\text { Interpreted the data and } \\
\text { revised the manuscript for } \\
\text { intellectual content }\end{array}$ \\
\hline $\begin{array}{l}\text { Martina } \\
\text { Bebin, MD, } \\
\text { MPA }\end{array}$ & $\begin{array}{l}\text { University of Alabama } \\
\text { at Birmingham }\end{array}$ & $\begin{array}{l}\text { Interpreted the data and } \\
\text { revised the manuscript for } \\
\text { intellectual content }\end{array}$ \\
\hline $\begin{array}{l}\text { Kevin } \\
\text { Bowling, } \\
\text { PhD }\end{array}$ & $\begin{array}{l}\text { HudsonAlpha Institute } \\
\text { for Biotechnology, } \\
\text { Huntsville, AL }\end{array}$ & $\begin{array}{l}\text { Major role in the acquisition of } \\
\text { the data and interpreted the } \\
\text { data }\end{array}$ \\
\hline $\begin{array}{l}\text { Bruce R. } \\
\text { Korf, MD, } \\
\text { PhD }\end{array}$ & $\begin{array}{l}\text { University of Alabama } \\
\text { at Birmingham }\end{array}$ & $\begin{array}{l}\text { Major role in the acquisition of } \\
\text { data }\end{array}$ \\
\hline $\begin{array}{l}\text { Gregory S. } \\
\text { Barsh, MD, } \\
\text { PhD }\end{array}$ & $\begin{array}{l}\text { HudsonAlpha Institute } \\
\text { for Biotechnology, } \\
\text { Huntsville, AL }\end{array}$ & $\begin{array}{l}\text { Major role in the acquisition of } \\
\text { data }\end{array}$ \\
\hline $\begin{array}{l}\text { Gregory M. } \\
\text { Cooper, PhD }\end{array}$ & $\begin{array}{l}\text { HudsonAlpha Institute } \\
\text { for Biotechnology, } \\
\text { Huntsville, AL }\end{array}$ & $\begin{array}{l}\text { Major role in the acquisition of } \\
\text { data }\end{array}$ \\
\hline $\begin{array}{l}\text { Anna C.E. } \\
\text { Hurst, MD }\end{array}$ & $\begin{array}{l}\text { University of Alabama } \\
\text { at Birmingham }\end{array}$ & $\begin{array}{l}\text { Major role in the acquisition of } \\
\text { data }\end{array}$ \\
\hline $\begin{array}{l}\text { Eroboghene } \\
\text { E. Ubogu, } \\
\text { MD }\end{array}$ & $\begin{array}{l}\text { University of Alabama } \\
\text { at Birmingham }\end{array}$ & $\begin{array}{l}\text { Design and conceptualized the } \\
\text { study and revised the } \\
\text { manuscript for intellectual } \\
\text { content }\end{array}$ \\
\hline
\end{tabular}

\section{References}

1. Yanagisawa H, Schluterman MK, Brekken RA. Fibulin-5, an integrin-binding matricellular protein: its function in development and disease. J Cell Commun Signal 2009; 3:337-347.

2. Auer-Grumbach M, Weger M, Fink-Puches R, et al. Fibulin- 5 mutations link inherited neuropathies, age-related macular degeneration and hyperelastic skin. Brain 2011; 134:1839-1852.

3. Lotery AJ, Baas D, Ridley C, et al. Reduced secretion of fibulin 5 in age-related macular degeneration and cutis laxa. Hum Mutat 2006;27:568-574.

4. Safka Brozkova D, Lassuthova P, Neupauerova J, et al. Czech family confirms the link between FBLN5 and Charcot-Marie-Tooth type 1 neuropathy. Brain 2013;136:e232.

5. Cheng S, Lv H, Zhang W, et al. Adult-onset demyelinating neuropathy associated with FBLN5 gene mutation. Clin Neuropathol 2017;36:171-177. 


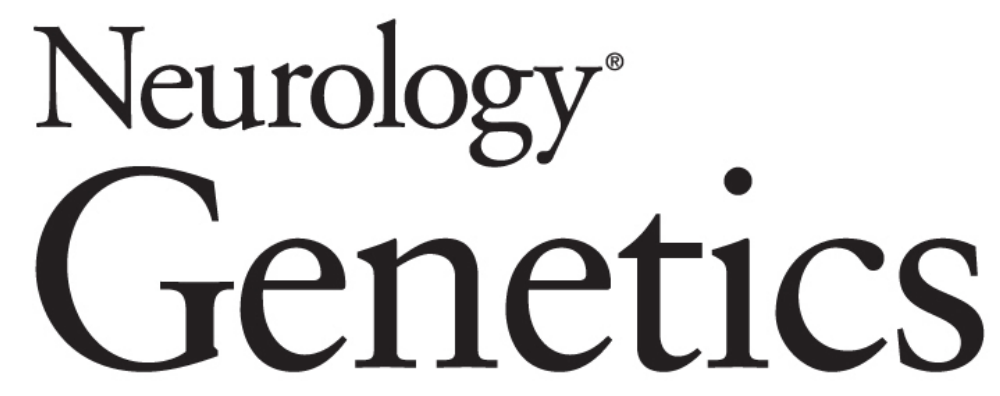

Fibulin-5 mutation featuring Charcot-Marie-Tooth disease, joint hyperlaxity, and
scoliosis Mohamed Kazamel, Michael A. Lopez, Martina Bebin, et al. Neurol Genet 2020;6;

DOI 10.1212/NXG.0000000000000476

This information is current as of June 25, 2020

\section{Updated Information \&} Services

References

Permissions \& Licensing

Reprints including high resolution figures, can be found at: http://ng.neurology.org/content/6/4/e476.full.html

This article cites 5 articles, 0 of which you can access for free at: http://ng.neurology.org/content/6/4/e476.full.html\#\#ref-list-1

Information about reproducing this article in parts (figures,tables) or in its entirety can be found online at:

http://ng.neurology.org/misc/about.xhtml\#permissions

Information about ordering reprints can be found online: http://ng.neurology.org/misc/addir.xhtml\#reprintsus

Neurol Genet is an official journal of the American Academy of Neurology. Published since April 2015, it is an open-access, online-only, continuous publication journal. Copyright Copyright ( 2020 The Author(s). Published by Wolters Kluwer Health, Inc. on behalf of the American Academy of Neurology.. All rights reserved. Online ISSN: 2376-7839.

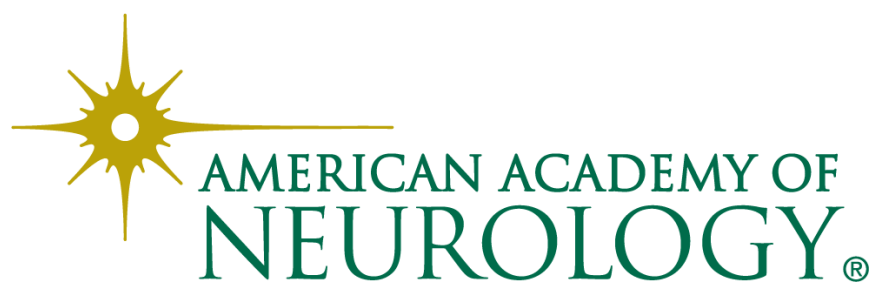

